\title{
Anthropometric Measurements, Hematological Indices \& Intelligence Quotient of Homeless Adolescents, Dar El Tarbia in Giza
}

\author{
Ghada M. I. El-Kllerbawy 1
}

\begin{abstract}
The anthropometric measurements (height/age, weight.»'age\& body mass index' (intelligence quotient (IO score) and some Hematological indices (I-Ib, TIBC\& serum iron) were assessed for fifty male adolescents residents aged 12-16 years of Dar El-Tarbia in Giza. The study revealed that about two third $(68 \%)$ of cases were stunted.I Meanwhile, $34 \%$ of them were under weight. None of the adolescents were above the ${ }^{6}$ normal height lage or weight/age according to the used standard reference (WIIO, 1995)The majority of the adolescents under study (84\%) had normal BMI. Concerning hemoglobin concentration, the results obtained were relatively close to reference $\mathrm{Hb}$ value (mean $\mathrm{Hb}$ level=11.8 $\mathrm{g} / \mathrm{dl}$ ). The majority of the adolescents $(90 \& 94 \%)$ had normal levels of TIB Candserum iron, respectively. The mean of standard deviation and IQ scores estimated to be $95.28+1502$ that considered close to the norm for IQ 1 test. There are significant correlations between time of residence in rehabilitation center and each of $\mathrm{Hb}$ concentration \&serum iron $(\mathbf{p}<\mathbf{0 . 0 5})$.
\end{abstract}

\section{INTRODUCTION}

Homeless children were defined as children less than 18 years old males or females, whose families and /or community have been unable to meet their basic needs due to social and economic problems, and who spend most or all of their time on the street with minimal or no contact with their families. Lack of supervision and protection or guidance, would make them vulnerable to a wide range of health and psychological hazards and exploitation violating their basic right [National Council of Childhood and Motherhood (NCCM), 2004].

The health records of street (homeless) children at different Non Governmental Organizations (NGOs) revealed a discrepancy between recorded health problems and the complaints mentioned by street children themselves. The most common health problems included in NGOs were skin diseases, anemia, intestinal parasitic infections, tonsillitis, hair lice and otitis media (UNICEF, 2001).

Generally, mild to moderate levels of anemia found to be prevalent among one third of young Egyptian children \& adolescents according to WHO epidemiological criteria (WHO, 1995). Anemia and malnutrition showed a significant adverse impact on both mental and physical development (WHO, 2001 and ElZanaty \& way, 2001). WHO (2008) reported that anemia is a public health problem that affects populations in both rich and poor countries.

There are no official or reliable statistics on the problem of street children in Egypt. The closest indicator is therefore the number of children arrested of the 42 , 505 children arrested in 2001. with regard to the age of street children, random NGO sample suggest that 13 years was the average. A quarter of them was believed to be less than 12 years old, with two - third between 13 and 16 years old and only $10 \%$ over 17 (NCCM, 2004).

In recent years, the attention to the street children phenomenon has also increased, partly due to declarations from the national Council of Childhood and Motherhood (NCCM) under the auspice of the First Lady Susan Mubarak. A 'National Strategy to Protect, Integrate and Rehabilitate street Children' was also launched by the NCCM in March 2003. "Vulnerable to delinquency" this hinders are the work of NGOs by preventing them from reaching drop in centers for rehabilitation. The homeless children would need the protection and assistance rather than punishment (UNICEF, 2003).

Since there are very limited studies focused on physical and psychological development of such group.

Therefore, this study was conducted to assess anthropometric measurements, intelligence quotients (IQ) and some hematological indices as in one of the rehabilitation centers.

\section{MATERIALS AND METHODS}

The present study included a sample of fifty male adolescents residents, of Dar El-Tarbia in Giza aged 1216 years, who had spent time on the street before being institutionalized. Over a period of one year data were collected through personal interview with each subject to fill a specially designed questionnaire sheet including:

The anthropometric measurements including weigh, height, \& body mass index (BMI) were assessed according to Lee \& Nieman (2003).

According to WHO (1995b) the percentile ranking for height/age \& weight/age was evaluated as follows:

\footnotetext{
${ }^{1}$ Lecturer of Home Economics, Dept. of food sei. \& Tech., Fuc. Of Agric, ‘Cairo Univ.

Received October 9, 2008, Accepted December 31, 2008
} 
- Normal height/age or weight/age: height or weight within $5^{\text {th }}-95^{\text {th }}$ percentile.

- Stunted or under weight: height or weight being less than $5^{\text {th }}$ percentile.

- Over weight or over height: height or weight exceeding or equal $95^{\text {th }}$ percentile. follows:

According to Dennis (2001) BMI, was evaluated as

- Normal BM: BMI value at $5^{\text {th }}-<85^{\text {th }}$ percentile.

- Under weight: BMI value being less than $5^{\text {th }}$ percentile.

- Over weight: weight exceeding or equal $95^{\text {th }}$ percentile.

Hematological study: For each case, a venous blood sample was withdrawn for the analysis of blood hemoglobin concentration $(\mathrm{Hb})$ according to the procedure described by ICSh (1967), serum iron was determined calorimetrically as described by Ceriotti \&
Ceriotti (1980), total iron binding capacity (TIBC) was determined according to picardi, et al. (1972).

Intelligent Quotient (IQ) : IQ for each case was assessed according to the individual test of intelligence described by Saleh (1978).

Statistical analysis: Data was statistically analyzed according to Rajagopalan (2006) by using SPSS software program Version 11.

\section{RESULTS AND DISCUSSION}

Data in table (1) demonstrated the mean IQs scores of adolescents under study according to their ages. Form this table, it could be noticed that adolescents at different ages (13-16 years) had mean IQs scores within the average level, while those at age 12 years had means IQs close to the average. The mean and standard deviation of IQs scores for all subjects under study was $95.28 \pm 15.02$, close to the norm for this test and IQs ranged from 71 to 137. In this respect, El-Kherbawy (2004) reported that the mean and SD of IQs scores

Table 1. Mean \pm SD, median and range of $\mathrm{IQ}, \mathrm{Hb}$, height and Wight of adolescents.

\begin{tabular}{|c|c|c|c|c|c|c|}
\hline Age & (Years) & $\begin{array}{c}\text { IQ } \\
\text { (Score) }\end{array}$ & $\begin{array}{c}\text { HB } \\
\text { (g/dl) }\end{array}$ & $\begin{array}{c}\text { Height } \\
\text { (cm) }\end{array}$ & $\begin{array}{c}\text { Weight } \\
\text { (kg) }\end{array}$ & BMI \\
\hline \multirow[t]{6}{*}{12.00} & Mean & 89.00 & 11.65 & 139.5 & 36.00 & 18.47 \\
\hline & $\mathbf{N}$ & 6 & 6 & 6 & 6 & 6 \\
\hline & Std.Devitation & 7.746 & .65320 & 3.14643 & 3.16228 & 0.98056 \\
\hline & Median & 90.00 & 11.7000 & 139.0000 & 35.50000 & 18.6450 \\
\hline & Minimum & 74 & 10.50 & 135.00 & 32.00 & 16.80 \\
\hline & Maximum & 95 & 12.10 & 144.0 & 41.00 & 19.77 \\
\hline \multirow[t]{6}{*}{13.00} & Mean & 92.22 & 11.21 & 144.22 & 38.66 & 18.58 \\
\hline & $\mathbf{N}$ & 9 & 9 & 9 & 9 & 9 \\
\hline & Std.Devitation & 12.833 & 1.07987 & 4.08588 & 3.77492 & 1.58246 \\
\hline & Median & 91.00 & 11.7000 & 145.0000 & 40.0000 & 18.6700 \\
\hline & Minimum & 74 & 9.80 & 137.00 & 34.00 & 16.17 \\
\hline & Maximum & 115 & 12.50 & 150 & 44.00 & 20.54 \\
\hline \multirow[t]{6}{*}{14.00} & Mean & 96.67 & 11.87 & 145.61 & 39.71 & 18.65 \\
\hline & $\mathbf{N}$ & 21 & 21 & 21 & 21 & 21 \\
\hline & Std.Devitation & 16.228 & .84270 & 4.63116 & 5.44190 & 1.65122 \\
\hline & Median & 90.00 & 12.1000 & 146.00 & 41.00 & 18.8100 \\
\hline & Minimum & 71 & 9.00 & 136.00 & 30.00 & 15.73 \\
\hline & Maximum & 123 & 13.20 & 157.00 & 52.00 & 21.29 \\
\hline \multirow[t]{6}{*}{15.00} & Mean & 101.83 & 12.15 & 151.00 & 42.16 & 18.54 \\
\hline & $\mathbf{N}$ & 6 & 6 & 6 & 6 & 6 \\
\hline & Std.Devitation & 21.619 & .86891 & 7.37564 & 4.66548 & 2.19794 \\
\hline & Median & 98.5 & 11.95 & 150.00 & 41.50 & 18.72 \\
\hline & Minimum & 77 & 11.30 & 142.00 & 35.00 & 15.24 \\
\hline & Maximum & 137 & 13.20 & 164.00 & 49.00 & 21.78 \\
\hline \multirow[t]{6}{*}{16.00} & Mean & 94.88 & 12.53 & 149.37 & 45.12 & 20.18 \\
\hline & $\mathbf{N}$ & 8 & 8 & 8 & 8 & 8 \\
\hline & Std.Devitation & 13.163 & 1.81575 & 4.27409 & 12.26420 & 5.26824 \\
\hline & Median & 90.00 & 11.9500 & 149.5000 & 41.50000 & 17.7700 \\
\hline & Minimum & 83 & 11.30 & 143.00 & 36.00 & 16.85 \\
\hline & Maximum & 122 & 16.50 & 156.00 & 73.00 & 32.44 \\
\hline \multirow[t]{6}{*}{ Total } & Mean & 95.28 & 11.85 & 145.88 & 40.24 & 18.8500 \\
\hline & $\mathbf{N}$ & 50 & 50 & 50 & 50 & 50 \\
\hline & Std.Devitation & 15.020 & 1.11578 & 5.60117 & 6.80204 & 2.53527 \\
\hline & Median & 90.00 & 12.0500 & 146.0000 & 40.5000 & 18.6650 \\
\hline & Minimum & 71 & 9.00 & 135.00 & 30.00 & 15.24 \\
\hline & Maximum & 137 & 16.5 & 164.00 & 73.00 & 32.44 \\
\hline
\end{tabular}


of urban Egyptian school students aging 4 to $<15$ years old, were $104.05 \pm 24$ and $93.26 \pm 18.23$ for normal and anemic children, respectively.

Data in the same table also illustrate means of hemoglobin concentration $(\mathrm{Hb})$. Hemoglobin more than $12 \mathrm{~g} / \mathrm{dl}$ was observed for the ages of 15 and 16 years old. However, adolescents at ages 12. 13 and 14 years old had $\mathrm{Hb}$ means slightly lower than $12 \mathrm{~g} / \mathrm{dl}$ that ranged from 11.2-11.8 $\mathrm{g} / \mathrm{dl}$. The mean $\mathrm{Hb}$ level for the sample was $11.85 \pm 1.11 \mathrm{~g} / \mathrm{dl}$. Blood $\mathrm{Hb}$ ranged from 9-16.5 $\mathrm{g} / \mathrm{dl}$. It could be also noted that the minimum $\mathrm{Hb}$ level was $9.00 \mathrm{~g} / \mathrm{dl}$ at the age of 14 years. The results obtained were relatively close to reference $\mathrm{Hb}$ value. As the $\mathrm{Hb}$ concentration ranged $9-16.5 \mathrm{~g} / \mathrm{dl}$, none of the adolescents suffered from severe anemia. These results are in the same line with those reported by WHO $\left(1995_{\mathrm{a}}\right)$, which showed that most of the young Egyptian adolescents suffered from mild to moderate level of anemia according to WHO epidemiological criteria.

$F$ test revealed no significant difference between each of IQs scores and $\mathrm{Hb}$ levels at different ages, as F $=0.669$ and 1.817 , respectively.

Regarding means of weights and heights for adolescents under study Table (1) showed that, weights $\&$ heights means were increased ascendingly according to their ages. The means of heights were $(139.5,144.2$, $145.6,151.0 \& 149.4)$ and the means of weights were $(36.0,38.6,39.7,42.1 \& 45.1)$ at ages $12-16$ years, respectively.

F test showed a highly significant difference between mean heights of the adolescents at different ages. I-Iowever, these differences were not significant between mean weights at different ages as $\mathrm{F}=3.556$ \& 2.298 , in the same respective order.

In this respect, the National survey in Egypt on adolescents aging 10-19 years old over a period of one year 1997-1998, El-sahn, (2002) reported that the mean height for boys aging 12,13,14, 15 and 16 I years old were $143.2,150.9,156.4,160.5$ and $166.5 \mathrm{~cm}$. respectively. While, the mean weights accounted to 36.8 , $42.2,47-6,52.3$ and $59.2 \mathrm{~kg}$ in the same order.

The obtained results of means of the homeless the adolescents under study showed lower value of heights \& weights compared to those of the National survey on adolescents at the same ages. Meanwhile, these values as well as those obtained of the above mentioned National survey were lower than the standard according to the same used reference (WHOb, 1995).

Concerning means of BMI for the adolescents under study, Table (1) showed relatively close BMI means for the adolescents at the different ages except at 16 years old. The adolescents at 13 years old had similar mean value of BMI reference (WI-IOb. 1995). In addition the adolescents at age 16 years had mean of BMI (20.18) nearly close to the reference value. Adolescents at ages $14 \& 15$ years old had lower BMI means than the standards being (18.65 \& 18.54), respectively. On the contrary, adolescents at the 12 years old had BMI mean that slightly above the reference value (18.47). the reference value for BMI means were 17.87, 19.22, 19.92 and 20.63 of the adolescents aging 12, 14, 15 and 16 years old, respectively.

$F$ test showed no significant differences between means of BMI at different ages for the adolescents under study. In this concern, El-Sahn, (2002) reported that the means of weights heights and BMI for the adolescents increased ascendingly according to their ages.

Table (2) showed that about two third of the case $(68 \%)$ were considered stunted. While about one third of them were within normal heights. Most of the stunted adolescents belonged to $14,15 \& 16$ years old. On the other hand, these percentages decreased to be 2 and $4 \%$ in 12 and 13 years old in respective order. Thus, the majority of normal height cases were found in these ages. It could be also noted that none of the adolescents under study showed above normal height.

Table 2. Male adolescent's distribution according to their height / age

\begin{tabular}{|c|c|c|c|c|c|c|c|c|}
\hline \multirow{3}{*}{ Age (Year) } & \multicolumn{8}{|c|}{ Height / age } \\
\hline & \multicolumn{2}{|c|}{$\begin{array}{c}\text { Stunted } \\
\left(<5^{\text {th }}\right)\end{array}$} & \multicolumn{2}{|c|}{$\begin{array}{c}\text { Normal } \\
\left(5-95^{\text {th }}\right)\end{array}$} & \multicolumn{2}{|c|}{$\begin{array}{l}\text { Above Normal } \\
\text { Height }\left(>95^{\text {th }}\right)\end{array}$} & \multicolumn{2}{|c|}{ Total } \\
\hline & No & $\%$ & No & $\%$ & No & $\%$ & No & $\%$ \\
\hline 12 & 1 & 2 & 5 & 10 & ---- & --- & 6 & 12 \\
\hline 13 & 2 & 4 & 7 & 14 & ---- & ---- & 9 & 18 \\
\hline 14 & 18 & 36 & 3 & 6 & ---- & ---- & 21 & 42 \\
\hline 15 & 5 & 10 & 1 & 2 & ---- & ---- & 6 & 12 \\
\hline 16 & 8 & 16 & ---- & ---- & ---- & ---- & 8 & 16 \\
\hline Total & 34 & 68 & 16 & 32 & ---- & ---- & 50 & 100 \\
\hline
\end{tabular}


In this concern, the nutrition status assessment of preparatory school children in Ismalia Governorate by Abd El-Ghany (1998) revealed that 25\% of the boys were stunted. While Baba et al (1991) found that $38 \%$ of public school children were stunted, while only $10.55 \%$ of private school children were so stigmatized, Stunting is the result of chronic under nutrition over a long period of time [Egypt Demographic \& Health Survey (EDHS), 1992]. The height for age indicator reveals long standing under nutrition that needs a long time to be corrected

From table (3), it is obvious that all adolescents at ages 12 and 13 years old were within normal weight lage. Most of these cases with normal weight /age were at 14 years old. However, all the cases having under weight/ age were seen at the ages of 14, 15 and 16 years.

The weight for age indicator is much more sensitive to the current status of nutrition. It seems that adolescents had been subjected to a long standing malnutrition that might have been partially corrected by the ongoing rehabilitation center feeding program.

In this respect, Aly (1996) examining school children in Giza Governorate found that none of her cases suffered from under nutrition. However, Soliman (1994) reported that $3.2 \%$ of the sample demonstrated the prevalence of under nutrition. While, this percent was $11 \%$ for boys in preparatory school in Ismailia Governorate (Abd El-Ghany, 1998).

From table (4) and Fig (1) it could be noticed that the majority of adolescents under study (84\%) had normal BMI. While, $14 \%$ of them were blow the normal BMI and only one case considered obese, representing $2 \%$. In addition, data demonstrated that all the young adolescents aged 12 and 13 years old had normal BMI. The very small minority of adolescents (14-16 years old) showed lower BMI compared to their counterparts with normal BMI. None of them could be considered at risk of obesity (over weight). Such findings might be ascribed to affect of devoted nutrition and physical care to the adolescents in the rehabilitation center.

From table (5) and Fig (2) it could be noticed that fifth of adolescents sample (20\%) had above average and superior levels of IQs score. While, $46 \%$ of the adolescents had IQs scores within the average level. However, 34\% of them showed IQ score below the average. UNICEF (2001) reported that children resident of governmental institutions have a higher degree of psychosocial adjustment than those children who reside on the street. Such findings draw attention to the importance of children's rehabilitation in Governmental care centers and its role in adjusting the psychosocial status of homeless children.

Table 3. Male adolescent's distribution according to their Weight/age

\begin{tabular}{|c|c|c|c|c|c|c|c|c|}
\hline \multirow{3}{*}{ Age (Year) } & \multicolumn{8}{|c|}{ Weight / age } \\
\hline & \multicolumn{2}{|c|}{$\begin{array}{c}\text { Under weight } \\
\left(<5^{\text {th }}\right)\end{array}$} & \multicolumn{2}{|c|}{$\begin{array}{l}\text { Normal } \\
\left(5-95^{\text {th }}\right)\end{array}$} & \multicolumn{2}{|c|}{$\begin{array}{l}\text { Over weight } \\
\left(>95^{\text {th }}\right)\end{array}$} & \multicolumn{2}{|c|}{ Total } \\
\hline & No & $\%$ & No & $\%$ & No & $\%$ & No & $\%$ \\
\hline 12 & ---- & ---- & 6 & 12 & ---- & ---- & 6 & 12 \\
\hline 13 & ---- & ---- & 9 & 18 & ---- & ---- & 9 & 18 \\
\hline 14 & 8 & 16 & 13 & 26 & ---- & ---- & 21 & 42 \\
\hline 15 & 4 & 8 & 2 & 4 & ---- & ---- & 6 & 12 \\
\hline 16 & 5 & 10 & 3 & 6 & ---- & ---- & 8 & 16 \\
\hline Total & 17 & 34 & 33 & 66 & ---- & ---- & 50 & 100 \\
\hline
\end{tabular}

Data also demonstrated that none of the adolescents under study at the different ages exceeded the normal weight / age.

Table 4. Male adolescent's distribution according to their age and body mass inbox (BMI)

\begin{tabular}{|c|c|c|c|c|c|c|c|c|c|c|}
\hline \multirow{3}{*}{ Age } & \multicolumn{10}{|c|}{ Body mass inbox(BMI) } \\
\hline & \multicolumn{2}{|c|}{$\begin{array}{c}\text { Blow Normal } \\
\left(<5^{\text {th }}\right)\end{array}$} & \multicolumn{2}{|c|}{$\begin{array}{c}\text { Blow Normal } \\
\left(5^{\text {th }}<8^{\text {th }}\right)\end{array}$} & \multicolumn{2}{|c|}{$\begin{array}{c}\text { At risk of obesity } \\
\left(85-<95^{\text {th }}\right)\end{array}$} & \multicolumn{2}{|c|}{$\begin{array}{c}\text { Obese } \\
\left(\geq 95^{\text {th }}\right)\end{array}$} & \multicolumn{2}{|c|}{ Total } \\
\hline & No & $\%$ & No & $\%$ & No & $\%$ & No & $\%$ & No & $\%$ \\
\hline 12 & ---- & ---- & 6 & 12 & ---- & ---- & ........... & .......... & 6 & 12 \\
\hline 13 & ---- & ---- & 9 & 18 & ---- & ---- & ........... & .......... & 9 & 18 \\
\hline 14 & 4 & 8 & 17 & 34 & ---- & ---- & .......... & $\ldots \ldots \ldots$ & 21 & 42 \\
\hline 15 & 1 & 2 & 5 & 10 & ---- & ---- & ........... & ......... & 6 & 12 \\
\hline 16 & 2 & 4 & 5 & 10 & ---- & ---- & 1 & 2 & 8 & 16 \\
\hline Total & 7 & 14 & 42 & 84 & ---- & ---- & 1 & 2 & 50 & 100 \\
\hline
\end{tabular}


Table 5. Male adolescent's distribution according to their intelligence quotients

\begin{tabular}{lcc}
\hline Grades of I.Q test & No & \% \\
\hline Below average (70-89) & 17 & 34 \\
Average (90-110) & 23 & 46 \\
Above Average (111-120) & 6 & 12 \\
Superior & 4 & 8 \\
Total & 50 & 100 \\
\hline
\end{tabular}

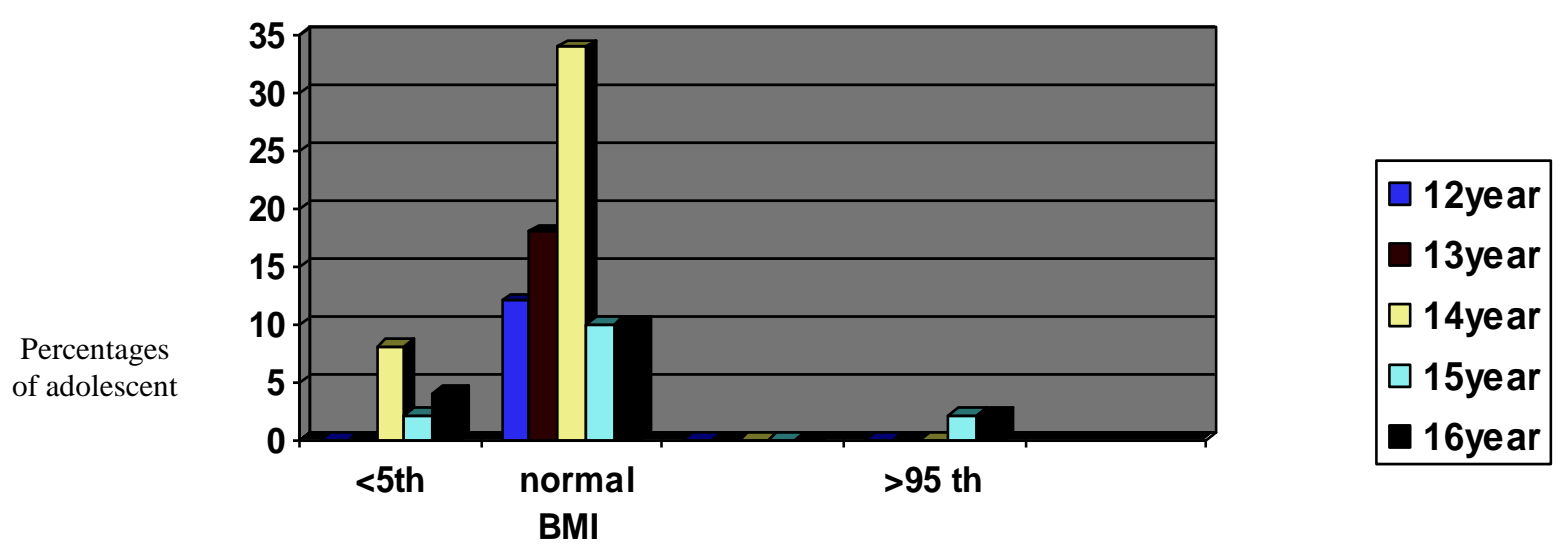

\section{Figure 1. Adolescents distribution according to their BMI}

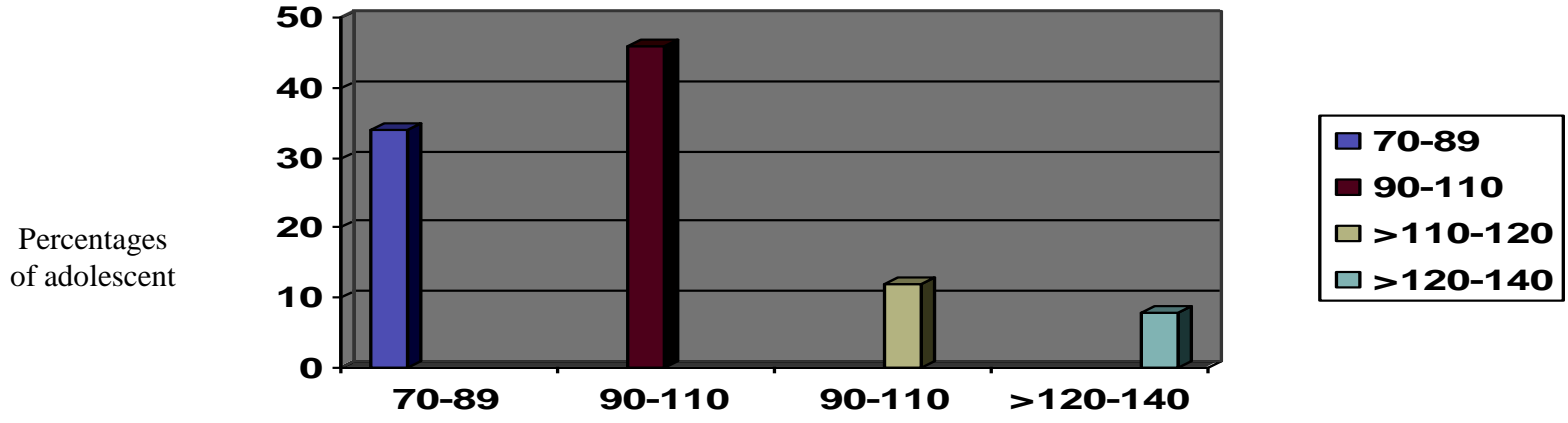

Figure 2. Adolescents distribution according to their IQs

Data in table (6) and Fig (3) revealed that nearly half of the cases had hemoglobin (Hb) levels less than $12 \mathrm{~g} / \mathrm{dl}$. While, the level of $\mathrm{Hb}$ for the remaining cases were $\geq 12 \mathrm{~g} / \mathrm{dl}$. The mean $\mathrm{Hb}$ level was $11.85 \pm 1.11 \mathrm{~g} / \mathrm{dl}$. Blood hemoglobin concentration ranged from 9 to 16.5 $\mathrm{g} / \mathrm{dl}$.

The mean $\mathrm{Hb}$ level was relatively close to the mean hemoglobin Concentration for Costarican adolescents aged (10-16) years old which $.12+1.0 \mathrm{~g} / \mathrm{dl}$ was .The result in this study also revealed high prevalence of anemia $(57 \%)$ in the adolescent (Monge -Rojas et al,2005)

Data in table (6) also illustrate mean and standard deviation of total iron binding capacity (TIBC) and Serum iron the mean value of TIBC for adolescents and the mean value of serum iron were within- normal range .IT could be also noticed from table (6) that the majority of adolescents (90 and 94\%) had normal levels of TIBC and serum iron, respectively. While a small percent of them (8 and 2\%) had below normal levels of TICB and serum iron in respective order .Meanwhile, a very limited number of them (one case) representing $2 \%$ had

TIBC above $4.2 \mathrm{mg} / \mathrm{L}$ and 2 cases of them (4\%) showed serum iron level exceeding $1.6 \mathrm{mg} / \mathrm{L}$. The ranges were $0.4-4.8 \mathrm{mg} / \mathrm{L}$ for TIBC and $0.4-2.6 \mathrm{mg} / \mathrm{L}$ for serum iron.

Concerning correlation coefficients among some variable $(\mathrm{Hb}$, age time o residence in care center and serum iron) were illustrated in table (7). There are significant correlation between $\mathrm{Hb}$ and each of age and time of residence $(\mathrm{P}<0.05)$. However, serum iron was highly significantly correlated with $\mathrm{Hb}(\mathrm{P}<0.01)$ and significantly correlated with the time of residence in care center $(\mathrm{P}<0.05)$. 
Table 6. Male adolescent's distribution according to hematological indices

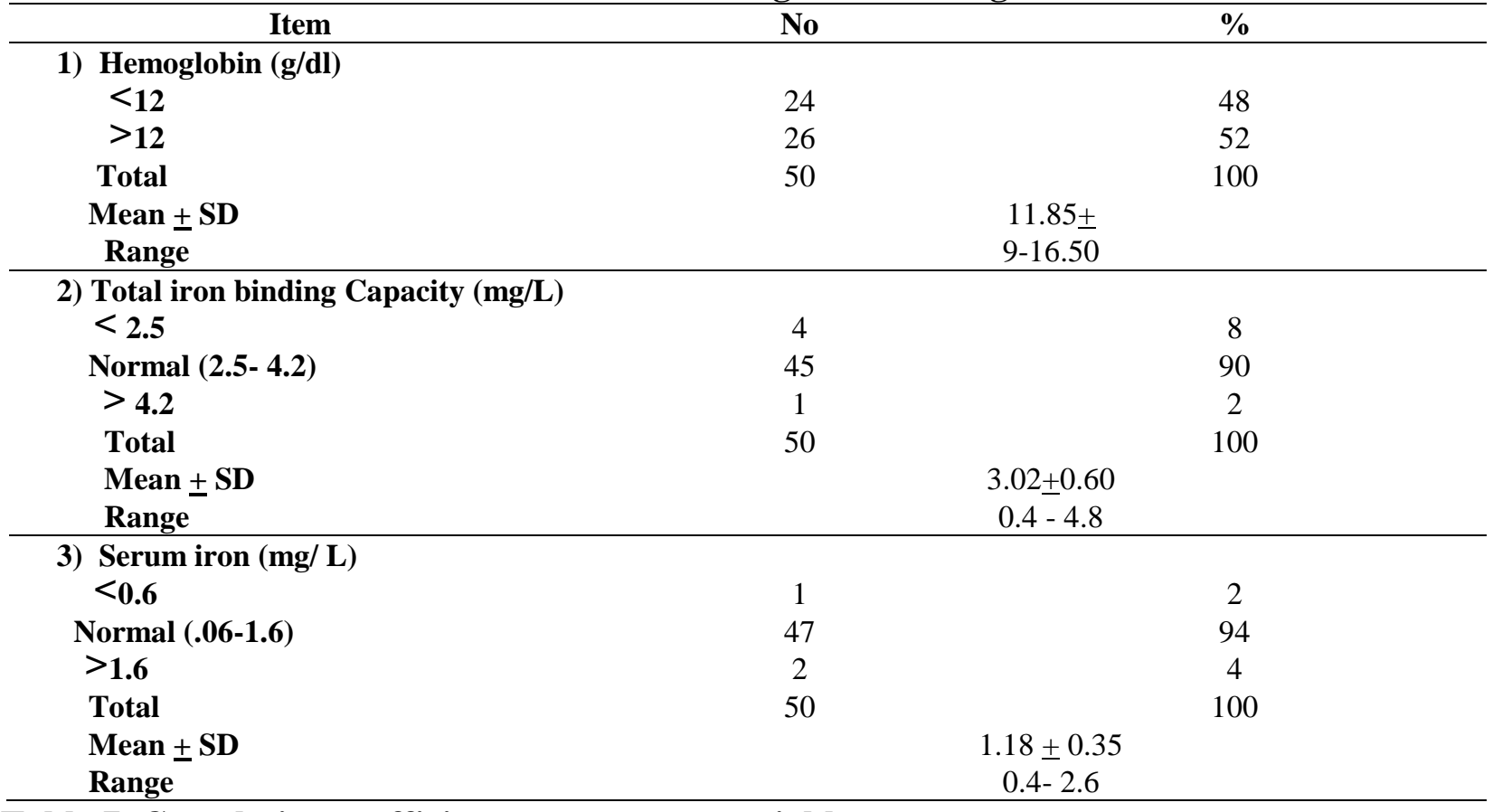

Table 7. Correlation coefficient among some variables

\begin{tabular}{cccccc}
\hline & HB & IQ & AGE & Time of residence in care center & Serum iron \\
\hline HB & & & & & \\
IQ & -.020 & & & & \\
AGE & $.333^{*}$ & .153 & & & \\
Time of residence in care center & $.311^{*}$ & .104 & .191 & & \\
Serum iron & $.368^{* *}$ & .186 & .055 & $.312^{*}$ & -.202 \\
TIBC & -.131 & -.156 & .210 & -.088 & \\
\hline
\end{tabular}

* Correlation is significant at the 0.05 level

** Correlation is Significant at the 0.01 level

Percentages of adolescent

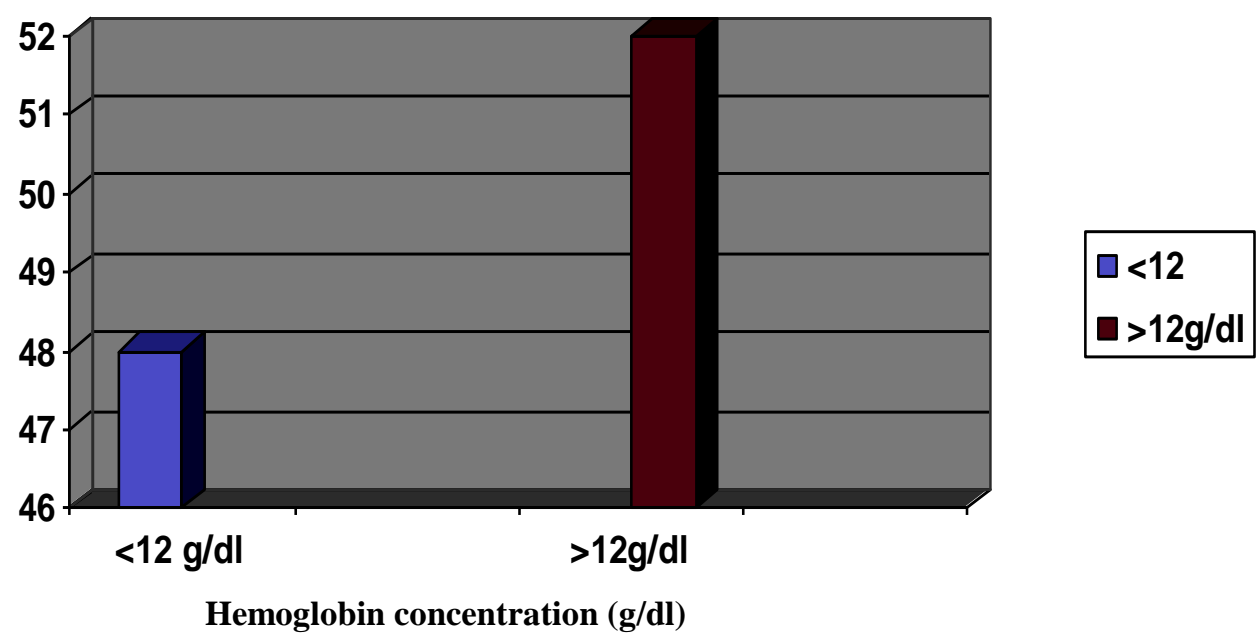

Figure 3. Adolescents distribution according to hemoglobin concentration (g/dl) 
Concerning the relationship between $\mathrm{Hb}$ concentration and age, Al -Sharbitti et al. (2003) showed that age was significantly correlated with $\mathrm{Hb}$ concentration of male adolescents two distinct socio economic areas.

The correlation between the time of residence and each of $\mathrm{Hb}$ and serum iron revealed the importance of residence in rehabilitation care center as both health and nutrition would be provided to the adolescents the longer time of residence the better serum iron and $\mathrm{Hb}$ level were observed.

\section{REFERENCES}

1- Abd El Ghany ,S.aM.(1998) .Assessment of nutrition status and its impact on scholastic achievement of children in Ismailia Governorate .Egyptian. J .of Nutrition XIII (1):1-17.

2- Al- Sharbatti, S.S.; Al-ward, N. J and Al-Timimi, D. j .(2003) Anemia among adolescent . Saudi med.J., 24(2):189-194.

3- Aly, L.A.A (1996). Nutritional status and its impact on scholastic achievement and intellectual development in some primary school children .MSc. Thesis, Fac. Of Home Economics, Helwan University, Egypt.

4- Baba,N.; Hamadeh, S. and Adra, N.(1991). Nutrition status of Lebanese school children from different socioeconomic backgrounds .Ecology of food nutrition, 5 (3): 183-192.

5- Ceriotti , F and Ceriotti,G (1980). "Improved direct specific determination of serum iron". Clin Chem., 26(2):327-331.

6- Dennis ,M.Styne (2001).childhood and adolescent obesity pediatric Clinic of North America,48(4):

7- EDHS (1992). Egypt Demographic and health Survey .Nutritional Population Council, Cairo, Egypt .Macro international Inc., Calverton, Maryland US: 153-157.

8- El Kherbawy, GM.I (2004) .Effect of iron deficiency anemia on the physical and cognitive development in urban children .Ph .D. Thesis, Fac. Of Agric., Cairo Univ. Egypt.

9- El-Zanaty, F. and Way, A. (2001). Egypt demographic and health Survey 2000. Ministry of health and Population. The population Council and ORC, Macro, Calverton, Maryland .USA.

10- ICSH (1967) .international Committees for Standardization in Hematology .Brit. J. of Hematology.13suppl. , 71.
11- Lee, RD. \& Nieman, D.C.(2003).Nutritional Assessment $.3^{\text {rd }}$ Edition .McGrow- Hill, Newyork. USA.

12- Mong-Rojas, R; Barrrantes, M ;Holst, I.; Nunez-Rivas, H. ;Alfaro, T.; Rodriguez S.; Cunningham, L.: Cambronero, P. ; Salazer, L and Herrmann, F.H.(2005).Biochemical indicators of nutritional status and dietary intake in Costa Rican Cabecar Indian adolescents .Food and Nutrition Bulletin,26(1):3:-6. The United Nation University.

13- NCCM (2004).A civil society forum for North and the Middle East on Promoting and protecting the Rights of Street children,3-6March, Cairo, Egypt.

14- Picardi, G.: Nyssen , M.and Dorche J. (1972) . J. Clin.ChemiActa.,40:219.

15- Rajagopalan, V.(2006).Selected Statistical Tests .New Age International (P) Ltd., Publishers Copy R.P248.

16- Soliman,F.S(1994).physical growth and intellectual abilities of cardiac children .ph.D. Thesis, Institute of post Childhood Studies Ein Shans University, Egypt .

17- UNICEF(2001) .Evaluation Report ,Rapid situation assessment report on the situation of street children in Cairo and Alexandria , including the children's drug abuse and health / nutritional status. UNICEF, Cairo.

18- UNICEF (2003). Human rights watches .www.unicef.Org/Egypt/protection.

19- WHO (1995a). The state of child health in the Eastern Mediterranean Region. WHO, Regional Office for the Eastern Mediterranean, Alexandria, Egypt.

20- Who(1995 b). Expert committee on physical status. The use and interpretation of anthropometry. Technical report series\# 854.Geneva, Switzerland.

21- WHO (2001).Iron Deficiency Anemia Assessment, Prevention, and control: A guide for program managers, WHO, Geneva, Switzerland.

22- WHO (2008).Word wide prevalence of anemia 19932005,WHO Global Database on Anemia .Geneva , Switzerland .

$$
\begin{aligned}
& \text { أحمد زكى صالح (1978) } \\
& \text { أختبار الدكاء المصور. الناشر مكتبة النهضة المصرية. } \\
& 1 \text { ف فكرات الصحن(2002). }
\end{aligned}
$$

الحالة التغذويـة للنشىء المصريين - مسح قومى (1997 - 1998) المجلة

العربية للغذاء والتغذية- المجلد الثالث، العدد السادس، وقائع ومدونات

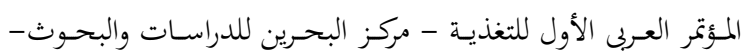

مملكة البحرين. الصفحات من 101-93. 


\section{الملخص العربي}

\section{المقاييس الأنثربومترية ومؤشرات الدم وحاصل الذكاء لدى المراهقين بدار التربية- محافظة الجيزة}

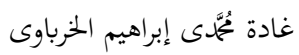

كمـا أن أغلبيـة المـراهقين موضـوع الدراسـة (84\%) كـانو في

الحدود الطبيعية بالنسبة لمؤشر كتلة الجسم.وفيما يتعلق بدرجة تركيز

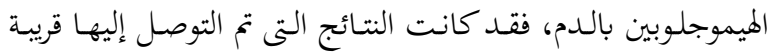

نسبيا من المرجعية القياسية لقيمة الهيموجلوبين فن الدم (متوسط

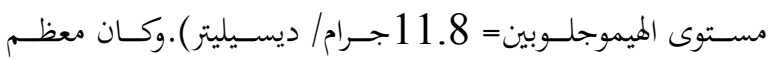

المراهقين(90\% و94\%) لديهم معدلات طبيعية من إجمالى طاقة

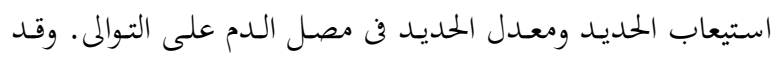

كـان متوسط حاصل الـذكاء 95.28 بانحــاف معيـارى قـدره +

15.02وهـو مـا يعتبر قريبـا مـن المعـدل الطبيعى لآختبـار الـذكاء مهاء

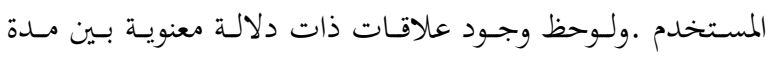

إلإقامة فن مركز إعادة التأهيل وبين كل من درجة تودئ تركيز الهيموجلوبين

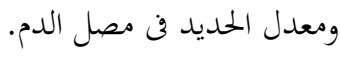

لقـد تم تقييم المقـاييس الأنثروبومتريـة (الطول/ العمـر، والوزن/

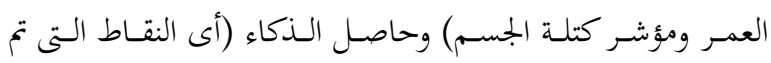

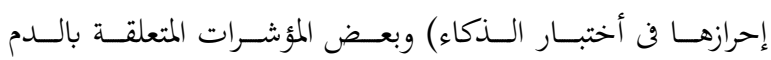

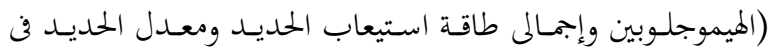

مصل الدم) بالنسبة لعدد خمسين من المراهقين الذكور المقيمين في "

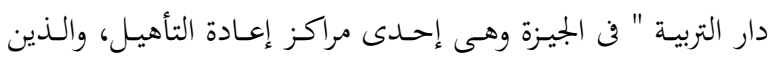

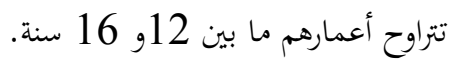

وقد أوضحت الدراسة أن حوالى ثلثى هذه الحالات (68\%)

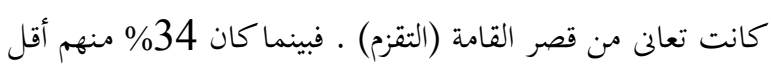

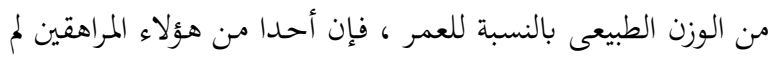

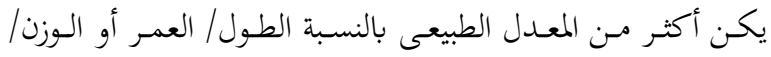

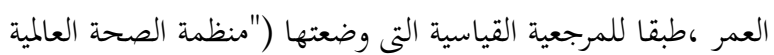

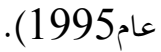

